\title{
BEYOND BAIDOO V. BLOOD-DZRAKU: SERVICE OF PROCESS THROUGH F ACEBOOK AND OTHER SOCIAL MEDIA PLATFORMS THROUGH AN INDIANA LENS
}

\author{
KRISTINA COLEMAN* \\ "[H] istory teaches that, as technology advances and modes of communication \\ progress, courts must be open to considering requests to authorize service \\ via technological means of then-recent vintage, rather than dismissing \\ them out of hand as novel."
}

\section{INTRODUCTION}

You've been wronged! You were involved in a car accident, which was completely the fault of the other driver. After getting the "runaround" from the other driver's insurance company, you decide to sue to recover damages for the several thousand dollars in medical expenses you have incurred. You filed your complaint with the court. ${ }^{2}$ You presented the summons to the clerk, which the clerk signed and sealed. ${ }^{3}$ Now, all you have to do is serve the defendant. Unfortunately, serving the defendant is not so easy. You tried to serve the defendant personally, but have been unable to locate him. You attempted service at his last known address, but it appears no one has lived there for a while. You even tried to serve the defendant at his place of employment, but you were told he was fired months ago. Your defendant appears to be in the wind.

You have one last Hail Mary. You decide to petition the court to allow you to serve the defendant through social media. ${ }^{4}$ If you lived abroad, you would have your choice of options: Facebook, ${ }^{5}$ Twitter, ${ }^{6}$ or even text message. ${ }^{7}$ However,

* J.D. Candidate, 2017, Indiana University Robert H. McKinney School of Law; B.S., 2011, Indiana University, Bloomington, Indiana. I thank my Faculty Advisor, Professor Jeffrey Cooper; my Executive Notes Editor, Elizabeth Little; and my Note Development Editor, Drew Kirages, for your guidance, insightful comments, and feedback throughout the note writing process. I also thank my mother, father, sister, and extended family for your continued love, support, and prayers.

1. FTC v. PCCare247 Inc., No. 12 Civ. 7189, 2013 U.S. Dist. LEXIS 31969, at*16-17

(S.D.N.Y. Mar. 7, 2013).

2. FED. R. CIV. P. 3.

3. FED. R. Civ. P. 4(b).

4. See infra Part IV.B for a brief definition of "social media."

5. John G. Browning, Served Without Ever Leaving the Computer: Service of Process via Social Media, 73 TEX. B.J. 180, 181 (2010) (describing how an Australian court, in MKM Capital v. Corbo, permitted service of process through a private Facebook message).

6. Id. at 182. (explaining how the United Kingdom's High Court permitted an injunction to be served via Twitter).

7. Claire M. Specht, Text Message Service of Process-No Lol Matter: Does Text Message Service of Process Comport with Due Process?, 53 B.C. L. REv. 1929, 1953 (2012) (detailing two Australian courts that have permitted service of process through text message). 
United States courts have not been as willing as their international counterparts to adapt to these emerging technologies, especially as it relates to service of process. ${ }^{8}$

This Note addresses the use of social media as a means for serving process within the United States. Specifically, it argues that courts, including those in Indiana, will need to strongly consider the use of Facebook and other forms of social media to effectuate an efficient system for serving defendants. Although courts' hesitance to not 'jump on the bandwagon of another fad" is warranted, statistics indicate that Facebook and social media, in general, are here to stay. ${ }^{10}$ Accordingly, courts should be willing to permit service of process via social media to "secure the just, speedy, and inexpensive determination of every action and proceeding." 11

Part I of this Note explores the historical progression of service of process, beginning with the seminal case of Pennoyer $v$. Neff ${ }^{2}$ and ending with Rio Properties, Inc. v. Rio International Interlink, ${ }^{13}$ which authorized electronic service of process. ${ }^{14}$ Part II details the Supreme Court of New York, New York County's holding in Baidoo v. Blood-Dzraku, ${ }^{15}$ the first United States court decision permitting service of process solely via Facebook. ${ }^{16}$ Part III provides a historical view of United States courts' handling of service of process via Facebook prior to the Baidoo v. Blood-Dzraku decision. Part IV analyzes the ability to expand service of process to other social media platforms, besides Facebook. Lastly, Part V begins by arguing that service of process via Facebook and other forms of social media should be admissible under Indiana law. It then provides a framework that Indiana courts can use if called on to address whether service of process via social media would be acceptable in a given case.

8. See infra Part III. Only a handful of cases have addressed the issue of service of process through social media, with the results being nearly equal as to the number of courts that have approved and denied such service. See infra Part III.

9. See, e.g., Joe Hand Promotions, Inc. v. Carrette, No. 12-2633-CM, 2013 U.S. Dist. LEXIS 109731, at *5 (D. Kan. July 9, 2013) ("[A]ssuming for the sake of discussion Facebook does not become obsolete and get replaced by another medium with more bells and whistles in the next few years, ....").

10. Andrew Perrin, Social Media Usage: 2005-2015, Pew Res. Ctr. (Oct. 8, 2015), http://www.pewinternet.org/2015/10/08/social-networking-usage-2005-2015/ [http://perma.cc/2HC6-LDJT] (explaining $65 \%$ of all adults and $76 \%$ of internet users use social networking sites). Furthermore, Facebook has been running strong for over ten years. Will Oremus, Facebook Was Born 10 Years Ago. Here's What It Looked Like, SLATE (Feb. 3, 2014, 9:12 PM), http://www.slate.com/blogs/future_tense/2014/02/03/facebook_10th_anniversary_social_networ k_turns_10_looks_back_at_its_history.html [https://perma.cc/7WC3-K9LU].

11. FED. R. CIV. P. 1.

12. 95 U.S. 714 (1877), overruled in part by Shaffer v. Heitner, 433 U.S. 186 (1977).

13. 284 F.3d 1007 (9th Cir. 2002).

14. Id. at 1018-19.

15. 48 Misc. $3 d 309$ (N.Y. Sup. Ct. 2015).

16. Id. at 317 . 


\section{Historical View of SERVice of Process}

A civil action commences once a complaint is filed with a court. ${ }^{17}$ However, for the court to enter a binding judgment against the defendant, the court must have jurisdiction over the defendant. ${ }^{18}$ The court has jurisdiction over the defendant once personal jurisdiction has been established and the defendant has received proper notice of the pending litigation. ${ }^{19}$

Service of process has a constitutional and statutory basis. ${ }^{20}$ The Fifth Amendment prohibits the federal government from depriving a person of "life, liberty, or property, without due process of law." ${ }^{21}$ This same prohibition is extended to the states through the Fourteenth Amendment. ${ }^{22}$ At a minimum, due process requires that, before an individual is deprived of life, liberty, or property, he or she must receive notice of the pending litigation and have an opportunity to be heard. ${ }^{23}$

The statutory basis for service of process is provided in the Federal Rules of Civil Procedure Rule 4 ("Rule 4"). ${ }^{24}$ Rule 4 governs service of process for proceedings brought within the United States district courts. ${ }^{25}$ Rule 4(e), which addresses service of process on individuals located within the United States, provides process may be served by: (1) following the law of the state where the district court is located or where service is made; (2) personal service; (3) service at the individual's place of abode with someone of suitable age and discretion; or (4) service upon the individual's agent. ${ }^{26}$ Rule 4(f), which addresses service of process on individuals located in a foreign country, provides that process may be served by: (1) any internationally agreed means of service that is reasonably calculated to give notice $;^{27}$ (2) a method prescribed by foreign authority or the

17. FED. R. Civ. P. 3.

18. Zenith Radio Corp. v. Hazeltine Research, Inc., 395 U.S. 100, 110 (1969) ("It is elementary that one is not bound by a judgment in personam resulting from litigation in which he is not designated as a party or to which he has not been made a party by service of process. The consistent constitutional rule has been that a court has no power to adjudicate a personal claim or obligation unless it has jurisdiction over the person of the defendant.").

19. World-Wide Volkswagen Corp. v. Woodson, 444 U.S. 286, 291 (1980).

20. See U.S. Const. amend. V.; U.S. Const. amend. XIV, § 1; FeD. R. Civ. P. 4.

21. U.S. CONST. amend. V.

22. U.S. CONST. amend. XIV, $\S 1$ (“[N] or shall any State deprive any person of life, liberty, or property, without due process of law ....”).

23. Mullane v. Cent. Hanover Bank \& Tr. Co., 339 U.S. 306, 313 (1950).

24. FED. R. CIV. P. 4.

25. Id.

26. FED. R. CIV. P. 4(e).

27. FED. R. Civ. P. 4(f)(1). "Internationally agreed means of service" includes service that is authorized by the Hague Convention on the Service Abroad of Judicial and Extrajudicial Documents ("The Hague Convention"). Id. The Hague Convention is a multilateral treaty among seventy-one party nations (includes member and non-member states) that provides the permissible 
foreign country's law that is reasonably calculated to give notice, ${ }^{28}(3)$ personal service ${ }^{29}$ (4) mail ${ }^{30}$ or (5) by other means not prohibited by international agreement, as the court orders. ${ }^{31}$

Although the establishment of personal jurisdiction and service of process are now seen as two separate, but related concepts, this was not always the case. ${ }^{32}$ Originally, service of process and personal jurisdiction were intertwined. ${ }^{33}$ In 1877, the United States Supreme Court in Pennoyer v. Neff addressed whether a monetary judgment rendered by an Oregon court against a non-resident defendant, who was not personally served and who did not appear before the Oregon court, was valid. ${ }^{34}$ Rather than personally serve the defendant, the plaintiff provided constructive notice by publication. ${ }^{35}$ The Court ultimately held that the judgment was "void for want of personal service of process." ${ }^{36}$ The Court established that personal service upon a defendant within the state's territory was required in order for a court to exert jurisdiction over the defendant. ${ }^{37}$ The Court noted that substituted service by publication, which was used in the case, would only be sufficient when the defendant could not be found within the forum state, but had property within the forum state that was attached at the beginning of the lawsuit, or when the litigation revolved around the property itself. ${ }^{38}$ The Court reasoned that if a binding judgment could be rendered against a defendant without personal service and upon mere publication, this would be used as a "constant instrument[] of fraud and oppression." ${ }^{\prime 39}$ As such, under the Pennoyer framework, a court was only able to establish jurisdiction over a defendant who: (1) personally appeared before the court; (2) was "found within the State"; (3) was a resident of the State; or (4) had property within the state that was attached at the beginning of the lawsuit. ${ }^{40}$

However, as the world became more mobile, courts began to dispose of this

methods for serving a defendant within a party nation's borders. Eric Porterfield, Too Much Process, Not Enough Service: International Service of Process Under the Hague Convention, 86 Temp. L. Rev. 331, 332 (2014); Hague Conference on Private Int'l Law, Status Table, HCCH, https:/www.hcch.net/en/instruments/conventions/status-table/?cid=17 [https://perma.cc/Q49KWW64] (last visited Feb. 5, 2017).

28. FeD. R. Civ. P. 4(f)(2)(A)-(B).

29. FED. R. CiV. P. 4(f)(2)(C)(I).

30. FED. R. CiV. P. 4(f)(2)(C)(ii).

31. FeD. R. CIV. P. 4(f)(3).

32. See Pennoyer v. Neff, 95 U.S. 714, 724 (1877), overruled in part by Shaffer v. Heitner, 433 U.S. 186 (1977).

33. Id.

34. Id. at 719-20.

35. Id. at 720 .

36. Id. at 721-22.

37. Id. at 724 .

38. Id. at 733 .

39. Id. at 726 .

40. Id. at 720 . 
territorial requirement. ${ }^{41}$ In 1940, in Milliken v. Meyer, the United States Supreme Court addressed the issue of whether a Wyoming court's judgment was entitled to full faith and credit in a Colorado court. ${ }^{42}$ Meyer, a Wyoming resident, was "personally served with process in Colorado pursuant to the Wyoming statute[]," but did not personally appear before the court. ${ }^{43}$ Meyer asserted that the judgment of the Wyoming court was void because it violated the due process rights granted to him under the Fourteenth Amendment. ${ }^{44}$ The Court ultimately held that the Wyoming court's judgment was entitled to full faith and credit in a Colorado court. ${ }^{45}$ The Court found that "[d]omicile in the state is alone sufficient to bring an absent defendant within the reach of the state's jurisdiction for purposes of a personal judgment by means of appropriate substituted service." ${ }^{, 46}$ Furthermore, Meyer's due process rights were not violated because the personal service of process he received while in Colorado apprised him of the pending litigation. ${ }^{47}$ Thus, the Wyoming court still had personal jurisdiction over Meyer even though he was personally served with process in Colorado rather than at his usual place of abode. ${ }^{48}$

In 1945, in International Shoe Co. v. Washington, the United States Supreme Court addressed the issue of whether the state of Washington had the constitutional authority to levy a tax against a Delaware corporation and subject it to the personal jurisdiction of Washington's courts. ${ }^{49}$ The Court found that the corporation had rendered itself amenable to the personal jurisdiction of Washington's courts. ${ }^{50}$ The Court held that a court could exert personal jurisdiction over a non-resident defendant if the defendant had "minimum contacts with [the forum state] such that the maintenance of the suit does not offend 'traditional notions of fair play and substantial justice." ${ }^{51}$ Furthermore, service of process via registered mail to defendant's home office along with service of process upon defendant's Washington agents, whose activities established the minimum contacts necessary for the court to exert personal jurisdiction over the defendant, provided sufficient notice of the suit. ${ }^{52}$

In 1950, the Supreme Court in Mullane v. Central Hanover Bank \& Trust Co. established what has been regarded by courts as the constitutional standard for due process: notice that is "reasonably calculated, under all the circumstances, to apprise interested parties of the pendency of the action and afford them an

41. See Int'1 Shoe Co. v. Wash., 326 U.S. 310 (1945).

42. 311 U.S. 457,458 (1940).

43. Id. at 459 .

44. Id. at 460-61.

45. Id. at 462 .

46. Id.

47. Id. at 463-64.

48. Id. at 459-62.

49. 326 U.S. 310,321 (1945).

50. Id.

51. Id. at 316 (quoting Milliken v. Meyer, 311 U.S. 457, 463 (1940)).

52. Id. at 320 . 
opportunity to present their objections. ${ }^{, 53}$ This refers to the means that would be employed by an individual desiring to inform the absent party of the litigation. ${ }^{54}$ If the circumstances do not permit actual notice to the absent party, due process requires the method chosen for service of process to be "not substantially less likely" to provide notice than other "feasible and customary substitutes." Mullane addressed the issue of whether notice solely by publication in a local newspaper to beneficiaries of a common trust, some whose residences were known and others whose residences were unknown, comported with the due process requirements of the Fourteenth Amendment. ${ }^{56}$ The Court held that for those beneficiaries whose residences were unknown, service by publication comported with due process because it was no more likely to fail than any of the choices available to legislatures to prescribe. ${ }^{57}$ However, for those beneficiaries whose addresses were known, service by publication was inadequate because "it [was] not reasonably calculated to reach those who could easily be informed by other means." ${ }^{58}$

As technology advanced, U.S. courts slowly but surely permitted service of process through these technological advances. ${ }^{59}$ In 1980, in New England Merchants National Bank v. Iran Power Generation \& Transmission Co., the United States District Court for the Southern District of New York permitted service of process via telex. ${ }^{60}$ The case involved plaintiffs who were unable to serve Iranian defendants within the sixty days required by New York's attachment statute. ${ }^{61}$ Several factors, including the political climate in Iran, the breakdown in postal service, and the severance of diplomatic relations between Iran and the United States, had impeded service of process. ${ }^{62}$ The plaintiffs petitioned the court to permit a substitute form of service. ${ }^{63}$ The defendants argued that the Foreign Sovereign Immunities Act ("FSIA") provided the exclusive method for service of process, and thus no substitute form of service was permitted. ${ }^{64}$

53. 339 U.S. 306,314 (1950).

54. Id. at 315 .

55. Id.

56. Id. at 309-11.

57. Id. at $317-18$.

58. Id. at 319 .

59. See, e.g., Rio Props., Inc. v. Rio Int'1 Interlink, 284 F.3d 1007, 1018 (9th Cir. 2002); New England Merchants Nat'l Bank v. Iran Power Generation \& Transmission Co., 495 F. Supp. 73, 81 (S.D.N.Y. 1980); Broadfoot v. Diaz, 245 B.R. 713, 720 (Bankr. N.D. Ga. 2000).

60. 495 F. Supp. at 81 . Telex is a breed of telegraph service that links "one typewriter keyboard to another that prints copies, enabl[ing] subscribers to send messages and data directly to other subscribers throughout the world." Aaron R. Chacker, E-ffectuating Notice: Rio Properties v. Rio International Interlink, 48 VILL. L. REV. 597, 605 n.46 (2003).

61. New England Merchants Nat'l Bank, 495 F. Supp. at 76.

62. Id.

63. Id. at 78 .

64. Id. 
The court, however, concluded that FSIA did not preclude a substitute form of service. ${ }^{65}$ The court reasoned that the fourth method of service under FSIA was intended to allow for substitute modes of service ${ }^{66}$ Moreover, the court found that nothing in the FSIA restricted it from using the Federal Rules of Civil Procedure Rule 4 to fashion substitute service of process. ${ }^{67}$ After finding the defendants admittedly had actual notice of the pending litigation and were intentionally avoiding service of process, the court stated that "[j]ustice demands that a substitute form of service be formulated. ${ }^{, 68}$ The court found service of process via telex was reasonably calculated to provide the defendants with notice of the suit because there were still at least two companies that offered such service between the United States and Iran. ${ }^{69}$

In Broadfoot v. Diaz, the United States Bankruptcy Court for the Northern District of Georgia authorized service of process via "facsimile transmission, electronic mail, and mail to the defendant's last known address." ${ }^{70}$ The case involved a Chapter 7 trustee who sought recovery of damages from a former officer and director of a debtor-corporation. ${ }^{71}$ The trustee petitioned the court, pursuant to Rule 4(f)(3), to allow him to serve the defendant by facsimile transmission, electronic mail, and mail to the defendant's last known address. ${ }^{72}$ The court, allowing this service of process, found Rule 4(f)(3) did not prohibit service of process through these means. ${ }^{73}$ Rather, the rule was designed to provide the court with flexibility in tailoring the method of service of process to meet the specific facts of the case. ${ }^{74}$ Additionally, the court found service of process via facsimile, electronic mail, and mail to the defendant's last known address was reasonably calculated to provide the defendant with actual notice. ${ }^{75}$ Although the defendant refused to provide the trustee with a current mailing address, the defendant had provided the trustee with a facsimile number and electronic mail address and had indicated a preference for receiving communication through these methods. ${ }^{76}$ The court thus reasoned, "If any method[] of communication [was] reasonably calculated to provide . . notice, surely those communication channels utilized and preferred by the defendant himself must be included among

65. Id.

66. Id. at 79 (explaining that unlike the first three methods of service permitted under FSIA, the fourth method does not require a signed receipt from an authorized Iranian official before service is complete; rather, it allows for service of process through diplomatic channels).

67. Id. at 80 .

68. Id. at 81 .

69. Id. at $81 \mathrm{n} .4$.

70. 245 B.R. 713, 720 (Bankr. N.D. Ga. 2000).

71. Id. at 715 .

72. Id.

73. Id. at $720-21$.

74. Id. at 720 .

75. Id. at 721 .

76. Id. at 718 . 
them.",77

In Rio Properties, Inc. v. Rio International Interlink, in a matter of first impression, the United States Court of Appeals for the Ninth Circuit held service of process by email was an acceptable method of alternative service. ${ }^{78}$ Rio Properties, Inc. involved a trademark infringement claim against a foreign defendant. ${ }^{79}$ After unsuccessfully attempting to serve the defendant through conventional means, the plaintiff petitioned the district court for alternative service of process. ${ }^{80}$ The Ninth Circuit, in affirming the district court's grant of service of process via email, found that the district court had "properly exercised its discretionary powers to craft alternate means of service" under Rule 4(f)(3). ${ }^{81}$ Additionally, the Ninth Circuit found service of process via email comported with due process because the defendant had structured its business so that it could only be contacted via email and had indicated on its website that email was its preferred method of contact. ${ }^{82}$

\section{THE BAIDOO V. BLOOD-DZRAKU DECISION}

In a case of first impression, the Supreme Court of New York, New York County ${ }^{83}$ addressed the issue of whether a plaintiff-wife could serve her defendant-husband with a divorce summons solely via Facebook. ${ }^{84}$ The case involved a married couple who had never lived together. ${ }^{85}$ Although the plaintiff was able to communicate with her husband via telephone and Facebook, she had no physical address for her husband and he had refused to make himself available for personal service. ${ }^{86}$ Due to an inability to serve her husband through traditional means, the plaintiff petitioned the court for a "judicially-crafted method of service," namely serving her husband via Facebook. ${ }^{87}$

In order to grant the plaintiff's petition, the court established that the plaintiff would first have to demonstrate that both personal service and the alternative methods allowed under New York's Civil Practice Law and Rules ("CPLR") would be impracticable for effectuating service of process ${ }^{88}$ The court found the

77. Id. at 721 .

78. 284 F.3d 1007, 1017-19 (9th Cir. 2002).

79. Id. at 1012 .

80. Id. at 1013 .

81. Id. at 1016 .

82. Id. at 1018 .

83. This is a New York trial court.

84. Baidoo v. Blood-Dzraku, 48 Misc. 3d 309, 310 (N.Y. Sup. Ct. 2015).

85. Id. at 312 .

86. Id. at 312,316 .

87. Id. at 311 .

88. Id. at 311-17. New York's Civil Practice Law and Rules provides for three alternative methods for effectuating service of process: (a) substitute service upon a person of suitable age at the defendant's place of business or usual place of abode; (b) "nail and mail" service; and (c) service by publication. Id. at 311. A plaintiff may, however, petition the court to "go beyond [these] 
plaintiff met this requirement. ${ }^{89}$ The plaintiff had shown that personal service would be impossible because the plaintiff was unaware of her husband's address; "there [was] no billing address linked to his pre-paid cell phone"; the defendant was not in the DMV's records; and no forwarding address was provided to the post office. ${ }^{90}$ Moreover, given the circumstances, attempting to serve process via substitute service or "nail and mail" service would be futile, as well. ${ }^{92}$ Lastly, the court stated that service by publication "is essentially statutorily authorized non-service." ${ }^{" 3}$ It is service that is "almost guaranteed not to provide a defendant with notice" at all. ${ }^{94}$

After concluding service of process via personal service and the alternative methods allowed under the CPLR would be impracticable, the court then addressed whether service of process via Facebook would comport with the wellestablished constitutional principle of being "reasonably calculated, under all the circumstances, to apprise [the defendant] of the pendency of the action." pass constitutional muster, the court stated that the plaintiff would have to overcome several hurdles. ${ }^{96}$ The court's first concern was that the Facebook account to which the plaintiff sought to send the summons might not belong to the defendant. ${ }^{97}$ The court's second concern was that the defendant might not see the summons until after the time to respond had passed. ${ }^{98}$ The court's third concern was whether the circumstances required a backup means of service. ${ }^{99}$

The court found that the plaintiff had sufficiently addressed all of its concerns. ${ }^{100}$ The court acknowledged that it is possible to create a fake Facebook profile. ${ }^{101}$ However, the court was persuaded that the account in question actually belonged to the defendant based on a supplemental affidavit provided by the plaintiff in which she attached copies of exchanges that took place between her

specifically prescribed methods" and authorize a "judicially-crafted method of service." Id.

89. Id. at 312 .

90. Id.

91. Id. at 311 ("Nail and mail" service entails "affixing the summons to the door of a defendant's 'actual place of business, dwelling or usual place of abode,' and then . . . mailing a copy [of the summons] to the defendant's 'last known address' or 'actual place of business.'”).

92. Id. at 312 ("Both 'substitute service' and 'nail and mail' service require knowledge of the defendant's 'actual place of business, dwelling or usual place of abode.' The record establishes that plaintiff has been unsuccessful in obtaining either a business or home address for defendant.") (quoting CPLR 308).

93. Id. at 316.

94. Id.

95. Id. at 311-12 (quoting Hollow v. Hollow, 193 Misc. 2d 691, 696 (N.Y. Sup. Ct. 2002) (quoting Mullane v. Cent. Hanover Bank \& Tr. Co., 339 U.S. 306, 314 (1950))).

96. Id. at 314 .

97. Id.

98. Id. at 315 .

99. Id.

100. Id. at 317 .

101. Id. at 314 . 
and the defendant on Facebook, and in which she identified the defendant as the person in the photographs that appeared on the Facebook page. ${ }^{102}$ The court found that the defendant likely would see a summons sent via Facebook prior to expiration of the time to respond because the plaintiff's exchanges with the defendant indicated that the defendant regularly accessed his account. ${ }^{103}$ Moreover, because the plaintiff had the defendant's phone number, either she or her attorney could alert him that the summons was being sent to him via Facebook and for him to check his account. ${ }^{104}$ Lastly, the court found that the circumstances did not require a backup means of service. ${ }^{105}$ The court reasoned that because the plaintiff neither had an email address nor a street address for the defendant, there was a "compelling reason to make Facebook the sole, rather than the supplemental, means of service." 106 The court added that it would not require service by publication as a backup means because it is "essentially statutorily authorized non-service" and because of its prohibitive cost. ${ }^{107}$

Based on the fact that personal service and the alternative methods allowed under the CPLR would be impracticable and the court's finding that service of process via Facebook was "reasonably calculated to give [the] defendant notice that he [was] being sued for divorce," the court permitted the plaintiff to serve her defendant-husband using a private message through Facebook. ${ }^{108}$

\section{THE UnORTHOdOX AND UNPRECEDENTED Frontier of SERVICE OF PROCESS VIA FACEBOOK: A Historical VIEW OF ITS APPLICATION PRIOR TO BAIDOO V. BLOOD-DZRAKU}

Since 2012, several United States courts have been asked to authorize alternative service of process via social media. ${ }^{109}$ While the Supreme Court of New York, New York County permitted service of process solely via Facebook in the landmark Baidoo v. Blood-Dzraku decision, not all courts have been so

102. Id. at 314-15.

103. Id. at 315 .

104. Id.

105. Id. at 316 .

106. Id. at 315-16. The court noted that of the handful of cases that had authorized service of process via Facebook, those cases had only allowed service of process as a supplemental means. Id. In FTC v. PCCare247 Inc. and WhosHere, Inc. v. Orun, service of process via Facebook was allowed in conjunction with service of process via email. FTC v. PCCare247 Inc., No. 12 Civ. 7189, 2013 U.S. Dist. LEXIS 31969, at*18 (S.D.N.Y. Mar. 7, 2013); WhosHere, Inc. v. Orun, No. 1:13-cv-00526, 2014 U.S. Dist. LEXIS 22084, at*14 (E.D. Va. Feb. 20, 2014). In Noel B. v. Anna Maria A., service of process via Facebook was allowed in conjunction with mailing a copy of the summons to the defendant's last known address. No. F00787-13/14B, 2014 N.Y. Misc. LEXIS 4708, at *4 (Fam. Ct. Sept. 12, 2014).

107. Baidoo, 48 Misc. $3 \mathrm{~d}$ at 316-17.

108. Id. at 312-17.

109. See, e.g., Fortunato v. Chase Bank USA, N.A., No. 11 Civ. 6608, 2012 U.S. Dist. LEXIS 80594 (S.D.N.Y. June 7, 2012); Noel B., 2014 N.Y. Misc. LEXIS 4708. 
willing to permit such service. ${ }^{110}$ Rather, there has been a split among prior courts addressing the issue of service of process via social media. ${ }^{111}$ Slightly more than half of the earlier court decisions disallowed such service. ${ }^{112}$ Whereas the courts that permitted service of process via social media only allowed it as a supplementary mode of service. ${ }^{113}$

\section{A. Courts That Have Rejected Service of Process via Facebook}

In June 2012, the United States District Court for the Southern District of New York addressed the issue of service of process via Facebook. ${ }^{114}$ In Fortunato v. Chase Bank USA, N.A., defendant, Chase, received a default judgment and garnished the wages of plaintiff, Lorri Fortunato, to recover unpaid credit card debt. ${ }^{115}$ The plaintiff, who alleged that the credit card account had been fraudulently opened in her name, brought counterclaims against Chase for violation of the Fair Credit Reporting Act, abuse of process, and conversion. ${ }^{116}$ Chase later sought to implead Nicole Fortunato, the plaintiff's estranged daughter, on the basis that she was the one who fraudulently opened the account in her mother's name. ${ }^{117}$ After having no success locating Nicole Fortunato or her residence, Chase petitioned the court to authorize service of process by email, Facebook, publication, and substitute service upon Fortunato's mother-the plaintiff in the instant action. ${ }^{118}$

The court ultimately disallowed all of the requested methods for service of process, except for service by publication. ${ }^{119}$ Although service via Facebook would have met the statutory requirements of service of process, the court rejected service of process via this method, noting that such service was unorthodox and unprecedented. ${ }^{120}$ The court also raised concerns about the authenticity of a Facebook account ${ }^{121}$ and stated that there was no certainty that the Facebook account located actually belonged to Nicole Fortunato. ${ }^{122}$ Based on the fact that plaintiff could not authenticate the Facebook account, the court held service of process via Facebook was not "reasonably calculated to notify Nicole

110. Baidoo, 48 Misc. $3 \mathrm{~d}$ at 317; see infra Part III.A.

111. Baidoo, 48 Misc. $3 \mathrm{~d}$ at 313.

112. See infra Part III.A.

113. See infra Part III.B.

114. Fortunato, 2012 U.S. Dist. LEXIS 80594.

115. Id. at *1-3.

116. Id. at *1-2.

117. $I d$. at $* 2-3$.

118. Id. at *3.

119. Id. at $* 10$.

120. Id. at *6-7.

121. Id. at *7 ("Indeed, the Court's understanding is that anyone can make a Facebook profile using real, fake, or incomplete information ....”).

122. Id. at *7-8. 
of [the] proceedings." 123 The court, however, provided no criteria regarding what evidence would validate that a given Facebook account belonged to a defendant. ${ }^{124}$ Rather, the court appeared to merely dismiss this method of service of process as it would put the court in unchartered territory. ${ }^{125}$

In July 2013, the United States District Court for the District of Kansas addressed the issue of service of process via Facebook. ${ }^{126}$ Joe Hand Promotions, Inc. v. Carrette involved a claim of copyright infringement brought against an individual and corporation, both doing business as "EL TAPATIO." ${ }^{127}$ After several unsuccessful attempts to serve the defendants, plaintiff petitioned the court to authorize service via Facebook as the sole means of substituted service. ${ }^{128}$ The court decided it would "respectfully decline the invitation ... to 'like' Facebook." 29 Although it was clear that the plaintiff had exhausted all conventional methods of service of process, the court noted that to satisfy due process, the plaintiff would have to show that service of process via Facebook was "likely to reach the defendant, so that the defendant may have an opportunity to present his case." ${ }^{30}$ To do this, the plaintiff would have to provide the court with adequate evidence to prove the authenticity of the Facebook account. ${ }^{131}$ Here, the only evidence linking the Facebook profile to the defendants was the presence of two links to businesses that had names similar to the name of the defendants' business. ${ }^{132}$ There was no email address or other information provided on the Facebook page that could be used to authenticate the account. ${ }^{133}$ The court, in distinguishing this case from FTC. v. PCCare 247 Inc. ${ }^{134}$ held there was inadequate evidence to "conclude that the subject Facebook profile [was] current, active, or authentic." 135

In August 2013, the United States District Court for the Eastern District of Missouri also addressed the issue of service of process via Facebook. ${ }^{136}$ In Joe Hand Promotions, Inc. v. Shepard, the plaintiff attempted to serve the defendants utilizing a variety of methods: attempted service at the principal place of business; attempted service at the residence; and attempted service on defendants'

123. Id. at *6.

124. Id. at *6-8.

125. Id. at *6-7.

126. Joe Hand Promotions, Inc. v. Carrette, No. 12-2633-CM, 2013 U.S. Dist. LEXIS 109731

(D. Kan. July 9, 2013).

127. Id. at $* 1$.

128. Id. at *1-2.

129. Id. at *1.

130. Id. at *5.

131. Id. at $* 6$.

132. Id. at *7.

133. Id.

134. See infra notes $155-64$ and accompanying text.

135. Carrette, 2013 U.S. Dist. LEXIS 109731, at*6-7.

136. Joe Hand Promotions, Inc. v. Shepard, No. 4:12cv1728, 2013 U.S. Dist. LEXIS 113578

(E.D. Mo. Aug. 12, 2013). 
former attorney. ${ }^{137}$ Upon finding a Facebook page linked to one of the defendants, the plaintiff petitioned the court to permit service of process via Facebook. ${ }^{138}$ The plaintiff reasoned that because service of process via Facebook was similar to service of process via email, which is authorized by Rule 4(f)(3), service of process via Facebook should be permitted under such circumstances. ${ }^{139}$

In rejecting the plaintiff's request and ordering service by publication, the court made several key points. The Court began by distinguishing Rule 4(f)(3) from Rule 4(e). ${ }^{140}$ Rule 4(f)(3) applies to foreign defendants and the defendant in this case was domestic. ${ }^{141}$ Because the case involved a domestic defendant, Rule 4(e) applied. ${ }^{142}$ Under Rule 4(e), the plaintiff failed to meet the statutory requirement for service of process. ${ }^{143}$ Although Rule 4(e) allows service in accordance with state law, Missouri does not allow for electronic service of process. ${ }^{144}$ The only remedy permitted in Missouri for an evasive defendant is service of process by mail or publication. ${ }^{145}$ The court then stated, "[i]f [the] plaintiff [would be] unable to serve process via e-mail, it certainly has not shown that it can properly serve process via Facebook." ${ }^{146}$

In 2014, the Oklahoma Supreme Court addressed the issue of service of process via Facebook. ${ }^{147}$ In re Adoption of K.P.M.A. involved the termination of a father's parental rights for a child born out-of-wedlock and placed for adoption. ${ }^{148}$ After his rights were terminated, the father appealed the decision, arguing, inter alia, that he had received improper notice that he was the father. ${ }^{149}$ The mother had sent the father a Facebook message "informing him that she was pregnant and plann[ed] to give the child up for adoption." 150 The father testified that he did not see the message until sometime later and that he did not know how long the message had been in his inbox when it was read. ${ }^{151}$ The court held that the notice provided via Facebook did not satisfy the due process requirements of the United States or Oklahoma Constitutions. ${ }^{152}$ The mother could have used more direct means of relaying the message as she "knew where to find Father . . . and

137. Id. at $* 2$.

138. Id. at *3.

139. Id.

140. Id. at *3-5.

141. Id. at *3-6.

142. Id. at *5.

143. Id. at *6-7.

144. Id. at *5-6.

145. Id. at $* 6$.

146. Id. at *7.

147. In re Adoption of K.P.M.A., 341 P.3d 38 (Okla. 2014).

148. Id. at 40 .

149. Id. at 42 .

150. Id. at 40 .

151. Id.

152. Id. at 51 . 
had no qualms about doing so." 153 The court also noted that "Facebook . . . is an unreliable method of communication if the accountholder does not check it regularly or have it configured in such a way as to provide notification of unread messages by some other means." 154

\section{B. Courts That Have Accepted Service of Process via Facebook}

In 2013, the United States District Court for the Southern District of New York again addressed the issue of service of process via Facebook. ${ }^{155}$ This time, in FTC v. PCCare 247 Inc., the court authorized service of process of documents, other than the summons and complaint, via email and Facebook after the foreign defendants failed to comply with the terms of a preliminary injunction. ${ }^{156}$ In analyzing whether to permit service of process via email and Facebook, the court first noted that Rule 4(f)(3) governed because foreign defendants were involved. ${ }^{157}$ Rule 4(f)(3) allows a court to "fashion means of service on an individual in a foreign country, so long as the ordered means of service (1) is not prohibited by international agreement; and (2) comports with constitutional notions of due process." ${ }^{\text {5158 }}$ The court found that neither service via Facebook nor service via email were prohibited by international agreement based on the fact that: India had only objected to the means of service listed in Article 10 of The Hague Convention; service of process by email and Facebook are not included in that list; and "India has not specifically objected to them."159

The court then addressed whether service of process via email and Facebook would comport with due process. ${ }^{160}$ The court held that both service via email and service via Facebook comported with due process. ${ }^{161}$ In addressing service via Facebook, the court noted that the plaintiff had provided "ample reason for confidence that the Facebook accounts identified [were] actually operated by defendants": the accounts were registered with the same email addresses the court had on file; the defendants listed their job titles on their Facebook pages; and the defendants were "friends" with each other. ${ }^{162}$ Moreover, because the defendants

153. Id.

154. Id.

155. FTC v. PCCare247 Inc., No. 12 Civ. 7189, 2013 U.S. Dist. LEXIS 31969 (S.D.N.Y. Mar. 7, 2013).

156. Id. at *1-5. The FTC had submitted the summons and complaint to the Indian Central Authority, in accordance with The Hague Convention. Id. at *3. The FTC had also sent the documents by alternative means: email, FedEx, and personal service. Id. at *4. The FTC received confirmation of delivery from FedEx and the process server, but as of the time of the court's decision, the Indian Central Authority had not formally served the defendants. Id.

157. Id. at $* 1,6$.

158. Id. at $* 6$.

159. Id. at $* 9-11$.

160. Id. at $* 11$.

161. Id. at *12.

162. Id. at *15-16. 
ran an online business, used email to communicate with customers, and advertised their business on Facebook, the court found that it was highly likely service of process via email and Facebook would reach the defendants. ${ }^{163}$ Although service of process via Facebook "is a relatively novel concept," the court acknowledged that "history teaches that, as technology advances and modes of communication progress, courts must be open to considering requests to authorize service via technological means of then-recent vintage, rather than dismissing them out of hand as novel."164

In 2014, the United States District Court for the Eastern District of Virginia permitted service of process on a defendant believed to be abroad via email, Facebook, and LinkedIn. ${ }^{165}$ WhosHere, Inc. v. Orun involved claims of trademark infringement, unfair competition, and cybersquatting against a Turkish defendant. ${ }^{166}$ After the summons the plaintiff had sent to the Turkish Ministry of Justice, in accordance with The Hague Convention, was returned because the defendant could not be located, the plaintiff petitioned the court to allow service of process through email and social media accounts. ${ }^{167}$ The court, in applying Rule 4(f)(3), found such means of service were not prohibited by international agreement and would comport with due process. ${ }^{168}$ Service of process via email and Facebook was not prohibited by international agreement because, while Turkey had objected to the means of service listed in Article 10 of The Hague Convention, "Turkey has not specifically objected to service by email or social media networking sites." 169 The court held the means of service comported with due process on the basis that: (1) the defendant provided plaintiff with the email addresses and directed plaintiff to the social media accounts; (2) the social media accounts appeared to be regularly viewed by the defendant; (3) the social media accounts provided the defendant's full name and linked him to the "alleged infringing application"; and (4) the defendant's email, which contained the social networking accounts and email contacts, implied that these were his preferred methods of communication. ${ }^{170}$

In 2014, the Family Court of New York, Richmond County, also addressed the issue of service of process via Facebook. ${ }^{171}$ In Noel B. v. Anna Maria A., a father sought modification of his child support payments. ${ }^{172} \mathrm{He}$ tried several methods of effectuating service of process on the mother, such as serving the

163. Id. at *18.

164. Id. at *16-17.

165. WhosHere, Inc. v. Orun, No. 1:13-cv-00526, 2014 U.S. Dist. LEXIS 22084, at*1 (E.D. Va. Feb. 20, 2014).

166. Id.

167. $I d$. at $* 3-4$.

168. Id. at *8-11.

169. Id. at $* 9-10$.

170. Id. at $* 11-12$.

171. Noel B. v. Anna Maria A., No. F00787-13/14B, 2014 N.Y. Misc. LEXIS 4708 (Fam. Ct. Sept. 12, 2014).

172. Id. at *1. 
mother at her last known address, texting his children to try to get their mother's address, and even conducting a Google search, but was unable to find the mother's location. ${ }^{173}$ Consequently, the father petitioned the court to allow him to serve process via Facebook. ${ }^{174}$ The court noted that New York's Civil Practice Law and Rules ("CPLR") applied, and that it would only be able to grant this petition if the alternative methods for service of process allowed under the CPLR were impracticable. ${ }^{175}$ The court found the alternative methods for service allowed under the CPLR were impracticable, and permitted service of process via Facebook on the basis that the mother was an active user of Facebook, as gleaned from the fact that the mother "liked" photos that the father's wife posted on her Facebook page. ${ }^{176}$ However, after noting that the two courts that authorized service of process via Facebook only allowed it in connection with other means of service, the court also required the father to "follow up" by mailing a copy of the summons that would be sent via Facebook to the mother's last known address. ${ }^{177}$ The court required this even after it already recognized that prior service to the address failed and that the physical whereabouts of the mother were uncertain. ${ }^{178}$

\section{Expansion of Service of Process to Social Media Platforms OTHER THAN FACEBOOK}

This part contends that other social media platforms, besides Facebook, can be used to adequately effectuate service of process. This part begins by noting the factors which, based upon case law, must be present in order for these alternative methods of service to comport with due process. This section then explores the ability of various social media platforms to meet these factors.

\section{A. Requirements Needed to Show Social Media Service of Process Comports with Due Process}

Notice and the opportunity to be heard are at the heart of due process. ${ }^{179}$ An analysis of the cases that address the issue of service of process via Facebook reveals several factors that must be established for such service to comport with due process. The plaintiff must show the following:

1. The social media account in question actually belongs to the defendant; ${ }^{180}$

173. Id. at *1-2.

174. Id. at *1.

175. Id. at $* 3$.

176. Id. at *2-4.

177. Id. at *4.

178. Id. at *1-4.

179. In re Adoption of K.P.M.A., 341 P.3d 38, 50 (Okla. 2014).

180. See, e.g., Fortunato v. Chase Bank USA, N.A., No. 11 Civ. 6608, 2012 U.S. Dist. LEXIS 80594, at *7-8 (S.D.N.Y. June 7, 2012); Baidoo v. Blood-Dzraku, 48 Misc. 3d 309, 314 (N.Y. Sup. 
2. The defendant regularly uses the social media account, such that the defendant is likely to receive actual notice prior to the time in which he or she needs to respond $;{ }^{181}$ and

3. For defendants located within the United States, that the state's trial rules have a catchall provision ${ }^{182}$ that would allow for service of process through this alternative method, ${ }^{183}$ or

4. For defendants located abroad, that service of process through this alternative method is not prohibited by international agreement. ${ }^{184}$

\section{B. Ability of Service of Process via Other Forms of Social Media to Comport with Due Process}

"Social media generally refers to the set of online tools" that are devised to promote social collaboration. ${ }^{185}$ Popular social media platforms include: Facebook, LinkedIn, Twitter, Instagram, and Pinterest. ${ }^{186}$ Of the courts that have specifically addressed the issue of service of process via Facebook, three of the seven permitted such service. ${ }^{187}$ Of those three courts, one even allowed service of process via LinkedIn. ${ }^{188}$ As with Facebook, with the right set of facts, other forms of social media will also be able to comport with due process.

The key purpose behind due process is to provide the defendant with notice and the opportunity to be heard. ${ }^{189}$ This notice requirement is satisfied when the method used for serving process is "reasonably calculated, under all the circumstances, to apprise interested parties of the pendency of the action and

Ct. 2015).

181. See, e.g., Joe Hand Promotions, Inc. v. Carrette, No. 12-2633-CM, 2013 U.S. Dist. LEXIS 109731, at*4 (D. Kan. July 9, 2013); Baidoo, 48 Misc. 3d at 315.

182. See Alyssa L. Eisenberg, Keep Your Facebook Friends Close and Your Process Server Closer: The Expansion of Social Media Service of Process to Cases Involving Domestic Defendants, 51 SAN DiEGo L. REv. 779, 786-87 (2014) (using the term "catchall provision" to refer to state civil procedure rules that permit alternative methods of service of process as long as the method is reasonably calculated to provide the defendant with notice).

183. See, e.g., Joe Hand Promotions, Inc. v. Shepard, No. 4:12cv1728, 2013 U.S. Dist. LEXIS 113578, at*5-6 (E.D. Mo. Aug. 12, 2013).

184. See, e.g., WhosHere, Inc. v. Orun, No. 1:13-cv-00526, 2014 U.S. Dist. LEXIS 22084, at *6 (E.D. Va. Feb. 20, 2014); FTC v. PCCare247 Inc., No. 12 Civ. 7189, 2013 U.S. Dist. LEXIS 31969, at *9-11 (S.D.N.Y. Mar. 7, 2013).

185. Alysia Blackham \& George Williams, Australian Courts and Social Media, 38 Alt. L.J. 170, 170 (2013), http://heinonline-org.proxy.mckinneylaw.uits.iu.edu/HOL/Page?handle=hein. journals/alterlj38\&div $=43 \&$ start_page $=170 \&$ collection $=$ journals\&set_as_cursor $=45 \&$ men_tab $=$ srchresults [http://perma.cc/NL86-QNF2].

186. Maeve Duggan et al., Social Media Update 2014, Pew Res. Ctr. (Jan. 9, 2015), http://www.pewinternet.org/2015/01/09/social-media-update-2014/[https://perma.cc/3BD4-PCJ3].

187. See supra Part III.B.

188. See WhosHere, Inc., 2014 U.S. Dist. LEXIS 22084, at *1.

189. Mullane v. Cent. Hanover Bank \& Tr. Co., 339 U.S. 306, 314 (1950). 
afford them an opportunity to present their objections." 190 Or, where circumstances do not allow for actual notice to be effected, due process requires the method chosen for service of process to be "not substantially less likely" to provide notice than other "feasible and customary substitutes."

Based on case law, the key aspects for making sure service of process comports with due process are: ensuring that the account in question actually belongs to the defendant, and that the defendant is a regular user of the social media platform. ${ }^{192}$ As a social media platform meant to "connect the world's professionals," LinkedIn should, arguably, be less susceptible to fake profiles. ${ }^{193}$ LinkedIn is, in essence, an online resume. ${ }^{194}$ It allows a user to provide information regarding his or her career history, education, interests, and any other career-related information the user would like to share. ${ }^{195}$ A potential advantage of LinkedIn that could be valuable to authenticating a social media account is that LinkedIn does the "linking" and authenticating. ${ }^{196}$ During the registration process, individuals can authorize LinkedIn to access email addresses and contacts from the email account used to create the LinkedIn account. ${ }^{197}$ From there, LinkedIn matches the users in the individual's contacts with LinkedIn's membership database. ${ }^{198}$

Thus, for an individual who had prior communication with the now elusive defendant, the individual should be able to meet his or her authentication burden by showing the court: (1) prior email communications with the defendant; (2) that the email address used for prior communication is the email address associated with the LinkedIn account; and (3) that the individuals listed as "connections" on the defendant's LinkedIn account are family members or other individuals known to associate with the defendant. ${ }^{199}$ Furthermore, even if an individual has not had prior communication with the now elusive defendant, there are other ways that the individual should be able to authenticate the account. For instance, if the individual knows a little bit about the defendant's background, the individual

190. Id.

191. Id. at 315 .

192. See supra notes $180-81$ and accompanying text.

193. About Us, LINKEDIN (2015), https://www.linkedin.com/about-us?trk=hp-about [http://perma.cc/BL2Y-CXAX].

194. Perkins v. LinkedIn Corp., 53 F. Supp. 3d 1190, 1197 (N.D. Cal. 2014).

195. Profile-Overview, LinKEDIn, https://help.linkedin.com/app/answers/detail/a_id/15493/ bid/3/pid/2 [http://perma.cc/4WPA-WCAZ] (last visited Feb. 6, 2017).

196. Perkins, 53 F. Supp. 3d at 1197-98.

197. Id.

198. Id.

199. See, e.g., FTC v. PCCare247 Inc., No. 12 Civ. 7189, 2013 U.S. Dist. LEXIS 31969, at *15-16 (S.D.N.Y. Mar. 7, 2013); Baidoo v. Blood-Dzraku, 48 Misc. 3d 309, 314-15 (N.Y. Sup. Ct. 2015); Controlling Who Sees Your Connections List, LinKedIn, https://help.linkedin.com/app/ answers/detail/a_id/52/kw/connection [https://perma.cc/MZ9J-4L9V] (last visited Feb. 6, 2017). Once an individual becomes a " 1 st -degree connection" with another person, that person, by default, is able to see the other's connections. 
could try to persuade the court that the LinkedIn account belongs to the defendant by showing the court: (1) the individual pictured is the defendant (if a picture is provided); ${ }^{200}$ and (2) the job title and employer is that of the defendant's. ${ }^{201}$ Additionally, once an individual is "connected" with a person on LinkedIn, there are ways to gauge how frequently that connection engages with LinkedIn - similar to Facebook and other forms of social media, posts and "likes" are time-stamped. ${ }^{202}$ As such, it should be relatively easy to gauge how frequently a person utilizes this platform.

Like Facebook, Twitter also has several features that will allow someone to authenticate a page. In customizing a Twitter profile, users may enter their name, birthday, biography, and even their current location. ${ }^{203}$ Twitter also offers account verification. Verified accounts are identified with a "blue verified badge."204 Verification is used to "establish [the] authenticity of identities of key individuals and brands. ${ }^{205}$ However, if Twitter does one day expand this to the general public, this would be a "surefire" way of confirming that the social media account truly belongs to the defendant. There are also ways to gauge how frequently an individual is on Twitter. Each tweet a user posts is timed-stamped; thus, it is easy to tell whether it has been hours, days, or weeks since a person has been on Twitter. ${ }^{206}$ Moreover, even if a user does not create his own tweet, a user's reply to a tweet posted by someone else is also time-stamped. ${ }^{207}$

Additionally, service of process via social media also comports with due process because it is "not substantially less likely" to provide notice than other "feasible and customary substitutes." ${ }^{208}$ The current method of last resort for an elusive defendant is service by publication. ${ }^{209}$ This method of service places

200. See, e.g., Baidoo, 48 Misc. $3 \mathrm{~d}$ at 315.

201. See e.g., PCCare247 Inc., 2013 U.S. Dist. LEXIS 31969, at*16.

202. A visit to a user's homepage reveals the articles the user's connections liked and shared, along with updates the connections have made to their own profiles.

203. Customizing Your Profile, TwITTER (2015), https://support.twitter.com/articles/127871 [http://perma.cc/35FK-BK9T]. Obviously, if an individual does not provide personal information on his or her Twitter profile or has made his or her Twitter profile private, service of process via Twitter will likely not be permitted, as it would be nearly impossible to authenticate that the account actually belongs to the defendant. However, this Note is not arguing that service of process should be utilized in all cases. Rather, granting service of process via social media should be determined on a case-by-case basis.

204. FAQs About Verified Accounts, TwITTER, https://support.twitter.com/articles/119135 [https://perma.cc/DT8L-J7VU] (last visited Feb. 5, 2017).

205. Id.

206. A user's Twitter wall provides the user's tweets and the date or hours since the tweet was posted.

207. Comments to a user's tweets are posted in a sub-box of the main tweet. Upon clicking on the sub-box, the box enlarges, revealing the date the comment was made.

208. Mullane v. Cent. Hanover Bank \& Tr. Co., 339 U.S. 306, 315 (1950).

209. Eisenberg, supra note 182, at 808. 
notice in the local newspaper regarding the pending litigation. ${ }^{210}$ Yet, as several authors and even the courts indicate, this method of service of process is extremely flawed, especially in this day and age. ${ }^{211}$ As Justice Cooper stated in Baidoo v. Blood-Dzraku, service by publication "is essentially statutorily authorized non-service." ${ }^{212}$ It is service that is "almost guaranteed not to provide a defendant with notice" at all. ${ }^{213}$ These statements are further highlighted when one compares newspaper readership to social media usage. Between 1999 and 2015 , the percentage of individuals, nationally, who read any daily newspaper fell by at least twenty-two percent across all age groups. ${ }^{214}$ In 2015, readership for those between the ages of eighteen and forty-four was either under twenty percent or barely broke twenty percent. ${ }^{215}$ Even for those individuals aged sixty-five and older, only fifty percent of them read a newspaper daily, down from seventy-two percent in $1999 .{ }^{216}$ In contrast, social media usage has shot up in the past decade.$^{217}$ Social media usage among all adults increased from seven percent in 2005 to sixty-five percent in $2015 .{ }^{218}$ Although adults between the ages of eighteen and twenty-nine have always been the group most likely to use social media, even seniors are making strides with their social media use. ${ }^{219}$ Between 2005 and 2015, social media usage among those sixty-five and older increased seventeen-fold to thirty-five percent. ${ }^{220}$ Furthermore, seventy percent of Facebook users and thirty-six percent of Twitter users frequent these websites daily. ${ }^{221}$ Only the percentage of LinkedIn daily users fell below the daily percentage for newspapers. ${ }^{222}$

In addition to the fact that a greater percentage of Americans use social media on a daily basis rather than read the newspaper, service of process via a social media platform - pending proof of authenticity-is also more likely to provide

210. ServeNow Staff, What Is Service by Publication, ServeNow (Aug. 26, 2011), http://www.serve-now.com/articles/512/what-is-service-by-publication [https://perma.cc/BJS5C8J5].

211. See, e.g., Baidoo v. Blood-Dzraku, 48 Misc. 3d 309, 316-17 (N.Y. Sup. Ct. 2015); Jennifer Lee Case, Extra! Read All About It: Why Notice by Newspaper Publication Fails to Meet Mullane's Desire-to-Inform Standard and How Modern Technology Provides a Viable Alternative, 45 GA. L. REV. 1095, 1118-19 (2011); Eisenberg, supra note 182, at 808-10.

212. Baidoo, 48 Misc. $3 \mathrm{~d}$ at 316.

213. Id.

214. Newspapers: Daily Readership by Age, PEw RES. CTR.,http://www.journalism.org/mediaindicators/newspapers-daily-readership-by-age/ [https://perma.cc/8KST-KLCN] (last visited Feb. 5, 2017).

215. Id.

216. Id.

217. Perrin, supra note 10.

218. $I d$.

219. Id.

220. Id.

221. Duggan et al., supra note 186.

222. Id. 
notice of the pending litigation because it is directed at the defendant. ${ }^{223}$ Each social media account is tied to a specific individual, and assuming the person's account has not been hacked, is within the exclusive control of that individual. ${ }^{224}$ Hence, if it can be established that the account is the defendant's, and that the defendant regularly checks the account, service of process via social media should be reasonably calculated to apprise the defendant of the pending litigation.

\section{SERVICE OF PRocess IN INDIANA}

This final part argues that service of process via Facebook and other forms of social media should be a viable option under Indiana law. Section A addresses the permissibility of service of process via social media under Indiana law. Section B explores the modernization of Indiana courts. Lastly, Section C offers a framework that Indiana courts could use if called upon to address whether service of process via Facebook and other forms of social media would be acceptable in a given case.

\section{A. The Permissibility of Service of Process via Social Media in Indiana Courts}

Even if an alternative method of service of process comports with due process, the method must still meet the rules-based requirement in order to be permitted. ${ }^{225}$ For an individual wanting to serve a defendant believed to be located abroad, having a court approve service of process via an alternative means, such as social media, is relatively easy. Rule 4(f)(3) allows a defendant located abroad to be served "by [any] other means not prohibited by international agreement."226 Generally, courts approve service of process via Facebook on a defendant believed to be located abroad when the foreign country does not explicitly prohibit service of process through such means. ${ }^{27}$ Serving a defendant believed

223. Mullane v. Cent. Hanover Bank \& Tr. Co., 339 U.S. 306, 315 (1950) (“Chance alone brings to the attention of even a local resident an advertisement in small type inserted in the back pages of a newspaper, and if he makes his home outside the area of the newspaper's normal circulation the odds that the information will never reach him are large indeed."). Although "chance alone" would alert an elusive defendant to pending litigation where an ad is placed in the newspaper, service of process via social media would greatly increase the likelihood of a defendant receiving notice because the plaintiff would be sending a targeted message directly to the defendant's account.

224. For instance, to access one's Facebook account, the individual has to sign in with his or her email address or phone number and password. Moreover, because an individual's account is linked to his or her email address or phone number, another individual would not be able to access that account, unless that individual had the password and email address or phone number associated with the account.

225. See Fed. R. Civ. P. 4.

226. FED. R. CIV. P. 4(f)(3).

227. See, e.g., FTC v. PCCare247 Inc., No. 12 Civ. 7189, 2013 U.S. Dist. LEXIS 31969, at *9-11 (S.D.N.Y. Mar. 7, 2013) (holding service of process via email and Facebook on defendants believed to be in India was not prohibited by international agreement because "India has not 
to be located within the United States, however, poses a larger challenge. Alternative means of service is only permitted if a state's law for serving process allows that form of service. ${ }^{228}$ Unfortunately, not every state permits service of process via alternative means. ${ }^{229}$

At first glance, it would appear that Indiana falls within this category. ${ }^{230}$ Under Indiana Trial Rule 4.1, which governs service of process upon an individual whose name and address are known ${ }^{231}$ an individual may be served by (a) registered or certified mail; (b) personal service; (c) leaving process at the individual's usual place of abode; or (d) leaving process with the individual's agent. ${ }^{232}$ "However, if an individual cannot be located, Rule 4.9 (by way of Rule $4.5)^{\prime 233}$ grants Indiana Courts the ability to order service of process in any manner that comports with due process. ${ }^{234}$

When a defendant is elusive, Indiana Trial Rule 4.5 permits service in any "manner provided by Rule 4.9 (summons in in rem actions)." 235 Summons in in rem actions may be made (a) by service upon the defendant or his agent; (b) service in accordance with Indiana Trial Rule 4.1; (c) service by publication; or (d) "service ... outside [the] state in any other manner as provided by these rules." 236

Indiana Trial Procedure Rule 4.14(B) states,

Upon application of any party the court in which any action is pending may make an appropriate order for service in a manner not provided by these rules or statutes when such service is reasonably calculated to give the defendant actual knowledge of the proceedings and an opportunity to be heard. ${ }^{237}$

Service of process via social media is not provided by Indiana's Trial Rules. ${ }^{238}$ Furthermore, under the right circumstances, service of process via social

specifically objected to them").

228. FED. R. CiV. P. 4(e)(1).

229. See, e.g., Joe Hand Promotions, Inc. v. Shepard, No. 4:12cv1728, 2013 U.S. Dist. LEXIS 113578, at*6 (E.D. Mo. Aug. 12, 2013); Eisenberg, supra note 182, at 815-22 (2014). Appendix A provides a list of the states that allow service of process on an elusive defendant only by newspaper publication as well as a list of states that have a catchall provision. Id.

230. Eisenberg, supra note 182, at 816.

231. See generally In re Adoption of C.A.H., No. 49A02-1302-AD-129, 2013 Ind. App. Unpub. LEXIS 928 (Ind. Ct. App. 2013).

232. IND. R. TRIAL P. 4.1.

233. Gregory A. Neibarger \& Joshua Burress, Using Facebook to Provide Notice for Service of Process, IND. LAw. (May 20, 2015), http://www.theindianalawyer.com/column-using-facebookto-provide-notice-for-service-of-process/PARAMS/article/37202 [http://perma.cc/WLG6-PY92].

234. IND. R. TRIAL P. 4.14(B).

235. IND. R. TRIAL P. 4.5.

236. IND. R. TRIAL P. 4.9 (emphasis added).

237. IND. R. TRIAL P. 4.14(B).

238. See Ind. R. TRial P. 4.1-4.17. 
media is reasonably calculated to provide a defendant with notice of pending proceedings. ${ }^{239}$ Thus, because service of process via social media is not provided for in Indiana's Trial Rules, and service of process via social media can comport with due process under the right circumstances, service of process via social media should be a viable option in Indiana courts per Indiana Trial Rule 4.14(B).

\section{B. Indiana's General Acceptance of Technological Advances}

Indiana's recent efforts to modernize its court system also supports a finding that service of process via Facebook and other forms of social media should be a viable option in Indiana. In January 2015, in Chief Justice Rush's first State of the Judiciary, the Indiana Supreme Court made known its commitment to modernizing court operations. ${ }^{240}$ The process actually began in November $2014 .^{241}$ By February of the following year, the Indiana Supreme Court had selected Tyler Technologies to provide e-filing services for Indiana's courts. ${ }^{242}$ In May of 2015, "[t]he public gained access to all appellate case information" through Odyssey. ${ }^{243}$ By the end of the fiscal year, over half of Indiana's courts were using Odyssey to maintain records. ${ }^{244}$

In the 2016 State of the Judiciary, Chief Justice Rush again reported on the progress the court had made in expanding the use of technology within the state's judicial system. ${ }^{245}$ Chief Justice Rush indicated that electronic filing had already been implemented in Indiana's appellate courts as well as in Hamilton County. ${ }^{246}$ Furthermore, electronic filing will soon follow in six of the remaining ninety-one counties. ${ }^{247}$ Electronic filing is expected to be available in all Indiana counties by the end of $2018 .^{248}$

239. See supra Part IV.B.

240. Hon. Loretta H. Rush, Chief Justice of the Indiana Supreme Court, State of the Judiciary: Indiana Courts: Working to Fulfill the Promise of Justice (Jan. 14, 2015), http://www.in.gov/ judiciary/supreme/2502.htm [https://perma.cc/2PM8-VYWJ].

241. In re Court Tech., 20 N.E.3d 544 (Ind. 2014).

242. Odyssey is Indiana's new case management system that connects courts and governmental entities statewide. Odyssey Case Management System, courTs.IN.gov, http://www.in.gov/judiciary/admin/2666.htm [http://perma.cc/667Q-2VTC] (last visited Feb. 6, 2017); Ind. Supreme Court, Indiana Supreme Court Annual Report 2014-2015, at 5, http://www.in.gov/judiciary/supreme/files/1415report.pdf [https://perma.cc/N8HC-4SWQ] (last visited Feb. 6, 2017) [hereinafter ANNUAL REPORT].

243. See AnNuAl RePORT, supra note 242, at 5.

244. Id. at 5; Odyssey Case Management System, supra note 242.

245. Hon. Loretta H. Rush, Chief Justice of the Indiana Supreme Court, State of the Judiciary: A Constitution Powerful in its Simplicity, Clear in its Mandate (Jan. 13, 2016), http://www.in.gov/ judiciary/supreme/2505.htm [https://perma.cc/RL6Y-FVTY].

246. Id.

247. Id.; Odyssey Case Management System, supra note 242.

248. Statewide E-filing, COURTS.IN.GOV, http://www.in.gov/judiciary/4267.htm [http:// perma.cc/GM3E-9J6U] (last visited Feb. 6, 2017). 
Although Indiana has taken this step toward technological advancement, to date, no Indiana court has addressed the permissibility of service of process via Facebook or other forms of social media. ${ }^{249}$ Though there has not been a case where the court has directly addressed the issue of service of process via social media, an Indiana Court of Appeals case indicates that the court may be willing to permit service of process via social media under the right circumstances. ${ }^{250}$

In In re Adoption of C.A.H., a biological mother petitioned the court to set aside an adoption decree on the basis that service of process upon her was ineffective and hence the decree was void for lack of personal jurisdiction. ${ }^{251}$ The adoptive mother had tried various methods to serve process, including attempting to serve the biological mother at three different residences as well as her last known place of employment. ${ }^{252}$ When these attempts failed, the adoptive mother "perfected service via publication in the Indianapolis Recorder." 253 The biological mother alleged the "Adoptive Mother did not conduct a diligent search before resorting to service by publication" because the adoptive mother could have contacted the biological mother directly on Facebook. ${ }^{254}$ The court held service by publication was sufficient and the trial court had personal jurisdiction over the adoption proceedings. ${ }^{255}$

It is important to note that the Indiana Court of Appeals did not outright reject the idea of service of process via Facebook. Rather, the court stated that the Facebook argument was speculative because the biological mother presented no evidence indicating that a Facebook search of her name would reveal her address or contact information. ${ }^{256}$

A final factor supporting the idea that service of process via Facebook and other forms of social media should be a viable option in Indiana is the fact that the Indiana Rules of Trial Procedure permit electronic service of process. ${ }^{257}$ Indiana Trial Rule $86(\mathrm{G})(3)(a)$ provides that "Registered Users must serve all

249. Neibarger \& Burress, supra note 233. Furthermore, a search on LexisNexis revealed only two Indiana cases using the terms "service of process" and "Facebook." The precise steps of the search were: (1) entered "service of process" in the search box; (2) narrowed to Indiana; (3) entered "Facebook" in the search within results box. However, in neither case was service of process via Facebook attempted. Rather, the defendants argued that the plaintiffs had not diligently sought to serve them, as the plaintiffs could have directly contacted them on Facebook. See In re Adoption of C.A.H., No. 49A02-1302-AD-129, 2013 Ind. App. Unpub. LEXIS 928 (Ind. Ct. App. July 23, 2013); J.H. v. Ind. Dept. of Child Servs., No. 02A03-1112-JT-556, 2012 Ind. App. Unpub. LEXIS 911 (Ind. Ct. App. July 26, 2012). A similar search process using "LinkedIn" and "Twitter" yielded no results.

250. See In re Adoption of C.A.H., 2013 Ind. App. Unpub. LEXIS 928, at*13.

251. Id. at *1, 6-7.

252. Id. at *2-3.

253. Id. at $* 5$.

254. Id. at *11.

255. Id. at *14-15.

256. Id. at $* 13$.

257. IND. R. TRIAL P. 86. 
documents in a case upon every other party who is a Registered User through EService using the Indiana E-filing System." ${ }^{" 258}$ Although Indiana Trial Rule 86 is not currently applicable to all cases filed in Indiana, it will be once E-filing is fully integrated in Indiana courts, which is scheduled to occur by the end of $2018 .^{259}$ Because the Indiana Rules of Trial Procedure permit service of process via electronic service, under the right circumstances, Indiana courts should also consider allowing service of process via social media, which is just another form of electronic communication. ${ }^{260}$

\section{A Framework for Indiana's Handling of Service of Process via Facebook and Other Forms of Social Media}

Indiana Trial Rules allow for service of process in a manner not provided by the Rules if it comports with due process. ${ }^{261}$ Accordingly, Indiana courts should consider permitting service of process via Facebook and other forms of social media, under the right circumstances. In addressing the issue of service of process via social media, Indiana courts should adopt a framework that can be used to determine whether service of process should be permitted given the facts of the case. As required by Indiana Trial Rule 4.14, any party seeking to serve process via social media should petition the court for approval. ${ }^{262}$ The court should then perform a three-step analysis to determine whether service of process via Facebook or other forms of social media should be permitted. This analysis would look to (1) whether the defendant has exhausted traditional methods of service, (2) whether the social media account is authentic and truly the defendant's account, and (3) how often the defendant utilizes the account.

In the first step, the court should determine whether the plaintiff has exhausted the traditional methods of service of process. ${ }^{263}$ Because personal service of the complaint and summons is the best way to ensure that a defendant has notice of the litigation, as well as an opportunity to be heard, the traditional methods of serving process in accordance with Indiana Trial Rule 4.1 should be exhausted first. ${ }^{264}$ The court could require the plaintiff to file an affidavit

258. Id. E-Service is defined as "a method of serving documents by electronic transmission." IND. R. TRIAL P. 86(A)(6).

259. E-filing Implementation Schedule for Indiana Courts, COURTS.IN.GOV (Jan. 19, 2016), http://www.in.gov/judiciary/files/efiling-implementation-schedule.pdf [https://perma.cc/6TQQ7CU7]; Statewide E-filing, supra note 248.

260. Like E-Service, service of process via social media would also encompass electronic transmission as an individual must be connected to the Internet to access the social media platform.

261. IND. R. TRIAL P. 4.14.

262. Id.

263. See, e.g., Joe Hand Promotions, Inc. v. Shepard, No. 4:12cv1728, 2013 U.S. Dist. LEXIS 113578, at *7-8 (E.D. Mo. Aug. 12, 2013) (finding that the plaintiff had not exhausted all service efforts and thus had ample other avenues to use to effectuate service of process).

264. See Specht, supra note 7, at 1937 ("Personal service is regarded as the 'gold standard' means for serving process. Because personal service is the most reliable method of apprising 
demonstrating the steps the plaintiff has already taken to try to effectuate service. ${ }^{265}$ The court would want to look at factors such as the number of times service was attempted, the time of day service of process was attempted, and the methods used. ${ }^{266}$ The court would then want to balance whether those facts favor a determination that traditional methods of service of process were exhausted. ${ }^{267}$

In the second step, the court should determine whether the plaintiff has proven that the social media account in question actually belongs to the defendant. ${ }^{268}$ This also would require a balancing test. One factor the court could look at is whether the plaintiff has shown that the email address the court has on file, or another email address the plaintiff can prove belongs to the defendant, is the email address used to create the social media account. ${ }^{269}$ Another factor could be whether the plaintiff has proven that the person in the pictures on the social media account is actually the defendant. ${ }^{270} \mathrm{~A}$ third factor the court could examine is whether the plaintiff has proven that the defendant's "friends" on the social media account are actual friends or acquaintances of the defendant in "real life." ${ }^{271}$ Additionally, the court could give weight to other verifiable information. This may include an inquiry into whether the plaintiff has proven that the employers, job titles, hobbies, or any other information provided on the social media account correspond with the defendant's actual employers, job titles, or hobbies. ${ }^{272}$

In the third step, the court will want to consider whether the defendant uses the requested social media platform on a regular basis. ${ }^{273}$ To ensure uniform results, a standard threshold should be established regarding the maximum duration between posts and other interactions on the social media platform that would still warrant a classification of "active user." The court could refer to Google's metrics for measuring active users as guidance for establishing this threshold. ${ }^{274}$

defendants of the proceedings pending against them, plaintiffs often provide notice in this manner.").

265. See, e.g., Baidoo v. Blood-Dzraku, 48 Misc. 3d 309, 314-15 (N.Y. Sup. Ct. 2015). Plaintiff provided supplemental affidavit authenticating the defendant's Facebook page. Id. at 314. A similar method could be used to demonstrate that traditional methods of service of process had been exhausted.

266. See, e.g., Shepard, 2013 U.S. Dist. LEXIS 113578, at *2, 7-8.

267. Id. at *7-8.

268. See, e.g., FTC v. PCCare247 Inc., No. 12 Civ. 7189, 2013 U.S. Dist. LEXIS 31969, at *15-16 (S.D.N.Y. Mar. 7, 2013).

269. Id.

270. See, e.g., Baidoo, 48 Misc. $3 \mathrm{~d}$ at 314-15. This inquiry would only work if the defendant posts pictures of real people, rather than cars, flowers, etc.

271. See, e.g., PCCare247 Inc., 2013 U.S. Dist. LEXIS 31969, at*16.

272. Id.

273. See, e.g., Joe Hand Promotions, Inc. v. Carrette, No. 12-2633-CM, 2013 U.S. Dist. LEXIS 109731, at*4 (D. Kan. July 9, 2013); Baidoo, 48 Misc. 3d at 315.

274. Active Users, GoogLE(2015), https://support.google.com/analytics/answer/6171863?hl= 


\section{CONCLUSION}

As new technological advances have come onto the scene, U.S. courts have slowly but surely gotten on board. ${ }^{275}$ The current technological advancement now making its way through the courts is social media. ${ }^{276}$ Like it or not, Facebook and other forms of social media are here to stay. ${ }^{277}$ Accordingly, courts should strongly consider permitting service of process via Facebook and other forms of social media, under the right circumstances.

The first obstacle in permitting such service is proving that service of process through this medium is reasonably calculated to apprise the defendant of the pending litigation. ${ }^{278}$ However, this obstacle can be conquered where a plaintiff can prove that the social media account in question actually belongs to the defendant and that the defendant is a regular user of the social media platform. ${ }^{279}$ Furthermore, service of process via social media is "not substantially less likely" to provide notice than the current method of last resort-service via publication. ${ }^{280}$ Because service of process via social media can comport with due process under the right circumstances, if a plaintiff is able to establish the rulesbased requirement of service of process, a court should permit service of process through this medium. ${ }^{281}$

As indicated in Joe Hand Promotions, Inc. v. Shepard, the rules-based obstacle to allowing service of process via social media on an elusive defendant believed to be located within the United States is ensuring that the state has a catchall provision allowing service of process through this alternative method. ${ }^{282}$ Indiana has such a catchall provision because the Indiana Rules of Trial Procedure allow for service of process in a manner not provided by the Rules if it comports with due process. ${ }^{283}$ Hence, service of process via social media should be a viable option in Indiana under the right circumstances. By implementing an objective framework for determining when service of process via social media would be appropriate, Indiana courts can "secure the just, speedy, and inexpensive determination of every action and proceeding." 284

en [http://perma.cc/7NA5-Q4MK].

275. See, e.g., Rio Props., Inc. v. Rio Int'l Interlink, 284 F.3d 1007, 1018 (9th Cir. 2002); New England Merchants Nat'1 Bank v. Iran Power Generation \& Transmission Co., 495 F. Supp. 73, 81

(S.D.N.Y. 1980); Broadfoot v. Diaz, 245 B.R. 713, 720 (Bankr. N.D. Ga. 2000).

276. See supra Part II and Part III.

277. Oremus, supra note 10; Perrin, supra note 10.

278. Mullane v. Cent. Hanover Bank \& Tr. Co., 339 U.S. 306, 314 (1950).

279. See supra notes $180-81$ and accompanying text.

280. Mullane, 339 U.S. at 315; see supra Part IV.B.

281. See supra Part IV.B.

282. See No. 4:12cv1728, 2013 U.S. Dist. LEXIS 113578, at *5-6 (E.D. Mo. Aug. 12, 2013).

283. IND. R. TRIAL P. 4.14

284. FeD. R. CIV. P. 1. 